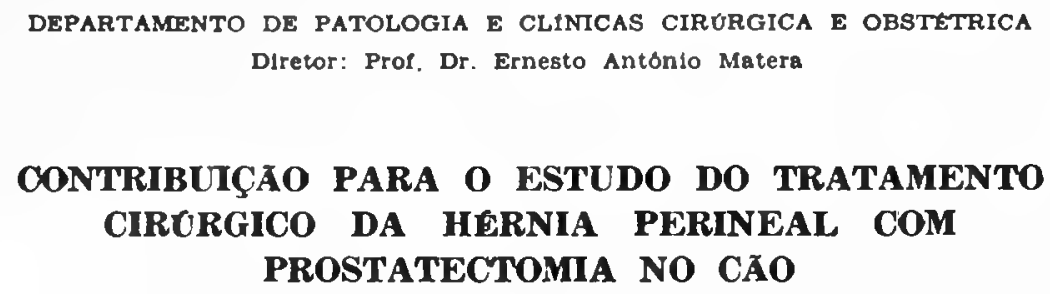

(CONTRIBUTION TO THE SURGICAL TREATMENT OF PERINEAL HERNIA WITH PROSTATECTOMY IN THE DOG)

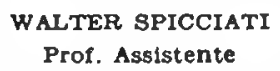

\title{
INTRODUÇÃO
}

A hérnia perineal, condição ainda que reconhecida há muitos anos e, não obstante, a relativa freqüência com que é encontrada, apresenta certas divergências acêrca de sua etiologia e patogênese, relações anatômicas da área envolvida e das técnicas cirúrgicas de correção, acrescentando-se o fato de que, sendo afeç̧ão de ocorrência em animais com idade avançada cuja labilidade é aumentada pela própria doença, revela-se ao cirurgião veterinário sob aspecto, aparentemente, desencorajador.

Entretanto, o exame geral meticuloso que cada caso isolado merece no sentido de preparo ao ato cirúrgico, a escolha da época propícia à cirurgia, contra-indicando-a se o estado do paciente assim o exigir, bem como, a utilização da melhor técnica operatória permitem àqueles que se propõem realizar tal emprêsa possibilidade de obtenção do almejado sucesso.

Os progressos alcançados na profilaxia da infecção e anestesia, principalmente, no que se refere à cirurgia dos pequenos animais, o aprimoramento do instrumental cirúrgico, os conhecimentos anatômicos da região e os cuidados pré e pós-operatórios vieram, decisivamente, contribuir na exeqüibilidade de correção da hérmia perineal.

- Trabalho apresentado a Faculdade de Medicina Veterlnária da Universidade de Sáo Paulo. para obtençáo do título de Mestre. 
Muito embora uma causa específica não tenha sido estabelecida na determinação dêste processo, aponta-se sua relação com doenças prostáticas sem, contudo, afirmar-se existência de causa direta ou relação de efeitos.

A observação de que, freqüentemente, o sucesso no tratamento cirúrgico tem, subseqüentemente, se desfeito com volta da condição - recidiva - quando não se realiza a prostatectomia, levou-nos a efetuá-la, como passo importante para a cura, tôdas as vêzes que a próstata doente estava presente no conteúdo herniário.

Finalmente, resta-nos salientar os avanços na técnica de prostacectomia pela via perineal como fator decisivo, sem o que não poderíamos atingir a finalidade a cue nos propusemos.

\section{SUMULA ANATÓMICA}

Não é, ábsolutamente, nosso intuito, realizar estudo completo da anatomia da região e órgãos que abordamos neste trabalho, com os pormenores dos tratados de anatomia, mas apenas, descrever o necessário sôbre o assunto que ora nos dedicamos, visando as diretrizes operatórias.

Assim, procuramos descrever, de acôrdo com MILLER e cols. (1968), os seguintes elementos:

Perineo.

Fossa ísquio-retal.

Fascia perineal.

Músculos esfincter externo do ânus, coccígeo, elevador do ânus, obturador interno e ligamento sacro-isquiático.

Uretra prostática.

Bexiga.

Próstata.

Cavidade pélvica.

O períneo é a região da passagem pélvica. Está limitado, dor. salmente, pela cauda; ventralmente, pela bôlsa escrotal e lateralmente, pela pele que recobre os músculos glúteo superficial, obturador interno e a tuberosidade isquiática. Profundamente, é demar- 
cado, dorsalmente, pela $3 .^{\mathrm{a}}$ vértebra coccígea; ventralmente, pelo arco isquiático e, lateralmente, pelo ligamento sacro-isquiático.

A fossa ísquio-retal é representada por depressão em forma de cunha localizada, lateralmente, à porção terminal pélvica do trato digestivo e urogenital. Os músculos coccígeo e elevador do ânus constituem seu limite lateral. A região mais caudal de seu limite medial, é constituida pelos muscu'os esfincter externo do ânus, dorsalmente e o retrator do pênis, no macho, ventralmente. O músculo obturador interno limita sua porção lateral baixa e ventral e o glúteo superficial, a região látero-dorsal.

Carnio-ventralmente, a fossa isquio-retal forma estreito fórnice onde origina-se o músculo coccigeo, adjacente à origem do músculo obturador interno, situado lateralmente.

Em cães bem nutridos, a fossa isquio-retal está repleta de tecido adiposo limitado, perifèricamente, pela pele.

Fascia perineal é o têrmo utilizado para incluir a fascia adjacente à cauda, anca e coxa, convergindo para a região anal e contendo a passagem pélvica. Está dividida em estrato superficial e profundo.

A fascia perineal superficial é delgada e está constituída de uma única camada de tecido conjuntivo frouxo, contendo numerosos vasos e nervos perineais de pequeno calibre.

A fascia perineal profunda recobre a superfície dorso-medial do músculo obturador interno e está aderida à porção dorsal da tuberosidade isquiática e à região adjacente ao ligamento sacro-isquiático; crânio-lateralmente, continua-se com a fascia profunda do músculo glúteo superficial. No macho, aplica-se, também, sôbre o músculo isquiocavernoso de ambos os lados.

A união da fascia na linha média é bastante densa e diferenciada, devido à presença de fibras colágenas.

O músculo esfincter externo do ânus representa o principal guardiāo do canal anal. Está composto de fibras musculares estriadas, apresentando-se como uma faixa mais larga na região dorsal, circundando o ânus e recobrindo o músculo esfincter anal interno, exceto caudalmente (figs. 1 e 2 ). 


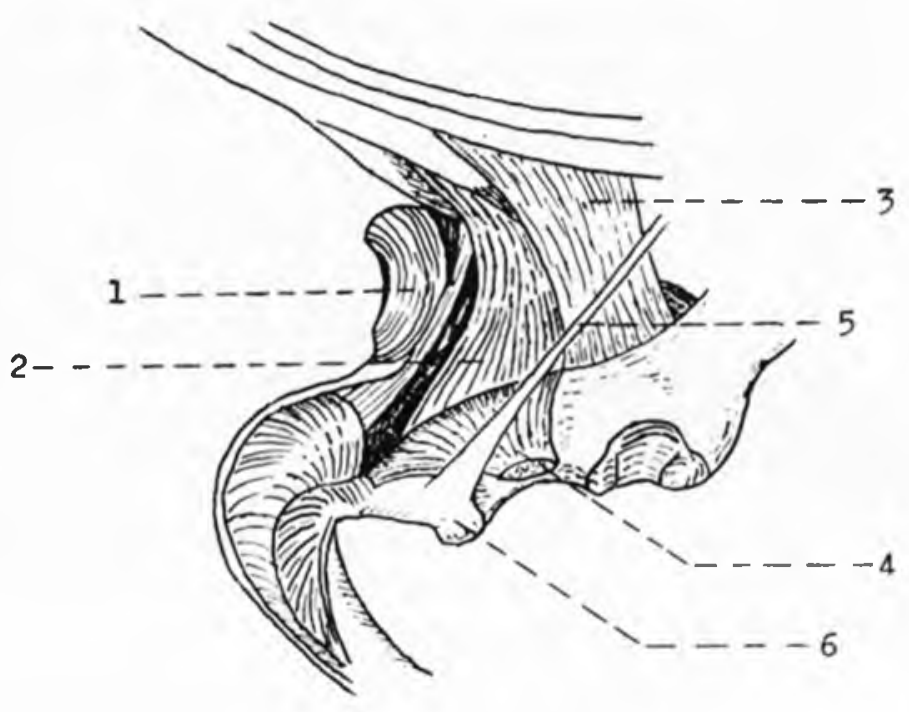

FIGURA 1 (Aspecto lateral)

1 - Músculo esfincter externo do fnus

2 - Músculo elevador do ánus ou cocclgeo medial

3 - Músculo coccigeo ou coccigco lateral

4 - Músculo obturador interno

5 - Ligamento sacro-isquítico

6 - Tuberosidade isquiática

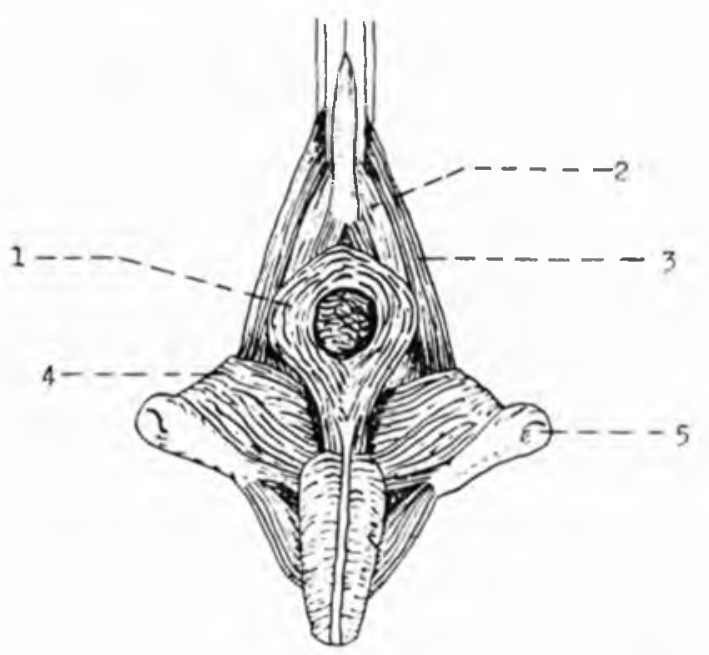

FIGURA 2 (Aspecto calidal)

1 - Músculo esfincter externo do ánus

2 - Músculo elevador do ânus

3 - Músculo coccígeo ou coccigeo lateral

4 - Músculo obturador Interno

5 - Ligamento sacro-1squíatico 
Seu bordo cranial está unido por fascia ao bordo caudal do músculo elevador do ânus. Dorsalmente, prende-se, principalmente, à fascia coccígea, ao nivel da $3 .^{\mathrm{a}}$ vértebra. Cêrca de metade de suas fibras circunda o ânus, ventralmente. As fibras remanescentes alcançam os músculos uretral e bulbo-cavernoso, no macho.

o músculo coccígeo ou coccígeo lateral é bem desenvolvido e origina-se na espinha isquiática através de estreito tendão, cranialmente ao músculo obturador interno. Medialmente, cruza o ligamento sacro-isquiático e estende-se sob a forma de leque à superfície lateral da cauda, inserindo-se sôbre os processos transversos da $2 .^{\mathrm{a}}$ e $5 .^{\mathrm{a}}$ vértebras coccígeas, entre os músculos intertransversários (figs. 1 e 2 ).

Recebe inervação dos ramos ventrais do $3 .^{\circ}$ nervo sacro.

Bilateralmente, sua ação é a de pressionar a cauda contra o ânus e órgãos genitais externos; unilateralmente, determina flexão lateral da cauda.

O músculo elevador do ânus, coccígeo medial ou retrator do ânus origina-se na borda medial do ilio, superfície interna do ramo do púbis e sôbre tôda a extensão da sínfise púbica, passando cranialmente ao músculo coccígeo lateral. É um músculo achatado e de forma triangular. Circunda parte do trato genital e reto. Caudalmente, invade a superfície interna do músculo obturador interno e, após diminuir em tamanho, surge na borda caudal do músculo coccígeo lateral, passa no interior da fascia coccígea e insere-se sôbre o processo hemal da $7 .^{\mathrm{a}}$ vértebra coccígea por meio de forte tendão, imediatamente vizinho ao seu par do lado oposto. Pode ser dividido em uma porção isquiática (músculo isquiococcígeo) e em uma parte iliopúbica (músculo iliopubococcigeo) entre as quais corre o nervo obturador (figs. 1 e 2 ).

A superfície profunda do músculo elevador do ânus está firmemente recoberta pela fascia pélvica.

Os ramos ventrais do último nervo sacro a $10^{\circ}$ nervo coccígeo suprem sua inervação.

Bilateralmente, sua ação é similar à do músculo anterior. Unilateralmente, dirige a cauda cranial $\mathrm{e}$ lateralmente; exerce, ainda, compressão sôbre o reto. Em combinação com os músculos elevadores da cauda, determinam ângulo entre a $6 .^{3}$ e $7 .^{a}$ vértebras coccígeas, característico da defecação.

Conforme PETTIT (1962), cirurgicamente, êste músculo é difícil de ser distinguido do coccígeo lateral, formando juntos uma espécie de diafragma pélvico, através do qual abrem-se para o ex- 
terior os órgãos gênito-urinários, constituindo, juntamente com a fascia perineal, as estruturas que mais interessam na hérnia perineal.

O músculo obturador interno cobre, internamente, o forame obturado. Origina-se medialmente a êste, sôbre a superfície pélvica do ramo do púbis, ísquio e arco isquiático. Suas fibras convergemse, lateralmente, e estendem-se sôbre o ligamento sacro-isquiático; voltam-se, em seguida, quase em ângulo reto, disto-lateralmente e formam forte tendão achatado que se estende profundamente, entre as bordas do músculo gêmeo da bacia (figs. 1 e 2 ).

O ligamento sacro-isquiático é constituido por cordão fibroso, aplainado $\mathrm{em}$ ambas as extremidades, estendendo-se da região caudo-lateral do ápice do sacro e processo transverso da $1 .{ }^{\mathrm{a}}$ vértebra coccígea ao ângulo lateral da tuberosidade isquiática. Localiza-se, em sua maior porção, no interior do músculo glúteo superficial. Determina o limite caudo-dorsal do forame isquiático (fig. 1).

O nervo pudendo, ramo do plexo lombo-sacro, misto, origina-se dos primeiros nervos sacros. Passando póstero-lateralmente aos músculos coccígeos, torna-se medial e penetra na fossa ísquio-retal juntamente com a artéria pudenda intema e respectiva veia, onde divide-se em ramo perineal e hemorroidário e no nervo dorsal do pênis.

Os ramos hemorroidários são motores voluntários e inervam o esfincter anal externo e vizinhanças do trato urogenital.

A artéria hemorroidária caudal, ramo da artéria pudenda interna, contribui para o suprimento da fascia perineal e torna-se o principal vaso das estruturas anais.

A porção prostática da uretra masculina estende-se da bexiga urinária à borda caudal da próstata onde se inicia a uretra membranosa.

Suas paredes, quando relaxadas, estão constituídas de número variável de pregas mucosas longitudinais e, quando distendidas, distinguem-se, apenas, as dorsalmente localizadas, formando a crista uretral.

A crista uretral possui um aumento de volume oval que faz projeção no lume do órgão, denominado de colículo seminal (colliculus seminalis), apresentando, em seu centro, diminuta abertura de pequena formação tubular, o útero masculino que se localiza crânio-dorsalmente na próstata. 
Os dutos deferentes abrem-se de cacia lado do colículo seminal não sendo suas aberturas vistas, macroscòpicamente.

Observam-se, ainda, numerosos dutos prostáticos abrindo-se na uretra, adjacentes e circundantes à crista uretral.

A bexiga urinária é dividida em três regiões, a saber: colo (cervix vesicae) que se liga com a uretra; corpo (corpus vesicae) e fundo (fundus vesicae).

Este órgão está suspenso por reflexões peritoniais que se estendem, de suas superfícies lateral e ventral às paredes lateral e ventral do abdômen, denominadas de ligamentos da bexiga.

O ligamento médio da bexiga ou ligamento umbilical médio une a superfície ventral do órgão à sinfise pélvica e linha média ventral da parede abdominal, sendo mediano, em posição e triangular, na forma. Caudalmente, termina, aproximadamente, no plano transverso que passa pelo meio da glândula prostática.

Os ligamentos laterais da bexiga ou umbilicais laterais dirigem-se das superfícies laterais dêste órgão à parede lateral do abdômen, sendo, também, triangulares na forma. São compostos por dupla camada de peritônio e entre elas passam os ureteres, vasos, nervos e apresenta considerável depósito de gordura.

Os ureteres abrem-se próximo ao colo da bexiga em área triangular denominada de trígono vesical.

Próximo a junção com a uretra localiza-se o esfincter da bexiga, composto de fibras musculares com direção oblíqua ou circular que, no macho, está situado profundamente à glândula prostática.

A próstata é um órgão músculo-glandular, encapsulado, circundando completamente a porção proximal da uretra masculina e o colo da bexiga. Seu tamanho e pêso normais variam na dependência da raça, idade e pêso corpóreo. Um sulco mediano longitudinal, paralelo à uretra, divide a próstata em dois lobos bem distintos.

Dependendo do grau de distensão da bexiga, as relações dêste órgão variam. Se a bexiga está repleta, a glândula pode situar-se na cavidade abdominal, cranialmente ao púbis ou, se estiver vazia, a 2 u $3 \mathrm{~cm}$ caudalmente à borda da pelve.

Sua superfície dorsal está separada da região ventral do reto por dupla camada de peritônio que guarnece o espaço retogenital. Ventralmente, a próstata está localizada, normalmente, sôbre a sín- 
fise pélvica da qual está, também, parcialmente isolada por dupla camada de peritônio.

Para GORDON (1960), a única e verdadeira cobertura peritonial do órgão está constituída por simples folheto peritonial representado pela camada dorsal do ligamento umbilical lateral, unida com a do lado oposto sôbre sua superfície dorsal. Descreve, ainda, em cães adultos, ligação fascial entre a região ventral do reto e o terço caudal da superfície dorsal da próstata.

Os dutos deferentes penetram na sua superfície dorsal, adjacentes um ao outro e em cada lado do plano mediano, percorrem, caudo-ventralmente, a porção dorsal da glândula e atingem a uretra lateralmente ao colículo seminal.

A próstata está constituída de numerosos túbulos glandulares localizados entre tecido conjuntivo intersticial contendo fibras musculares lisas. Trabéculas capsulares dividem-na em lóbulos. Os dutos excretores prostáticos abrem-se na uretra, junto à crista uretral.

De acôrdo com GORDON (1960), o principal suprimento sanguíneo dêstes órgãos que pode ser, realmente, distinguido pelo cirurgião, deriva das artérias umbilical e urogenital.

A a. urogenital origina-se do ramo visceral da a. ilíaca interna ao nível da $2{ }^{a}$ e $3 .^{a}$ vértebras sacras $\mathrm{e}$, invariàvelmente, divide-se em dois ramos: as artérias prostática-vesical e prostáticauretral.

A a. prostática-vesical dirige-se à bexiga onde recebe o nome de a. yesical caudal, terminando por anastomosar-se com a a. vesical cranial e vesical caudal do lado oposto. Envia, ainda, ramos para próstata, duto deferente, ureter e parede ventral dc reto.

A a. prostática-uretral dá a maioria dos ramos prostáticos, irriga a uretra e parede lateral do reto, anastomosando-se com ramos uretrais da a. pudenda interna.

A a. umbilical alcança a parede da bexiga e continua com $o$ nome de a. vesical cranial.

CAMPOS (1968), após estudo pormenorizado, descreve o comportamento das artérias urogenital e umbilical. Na apresentação comum (fig. 3), o ramo visceral da artéria hipogástrica ou ilíaca interna, divide-se na a. urogenital e em um ramo que se dirige para o reto. 


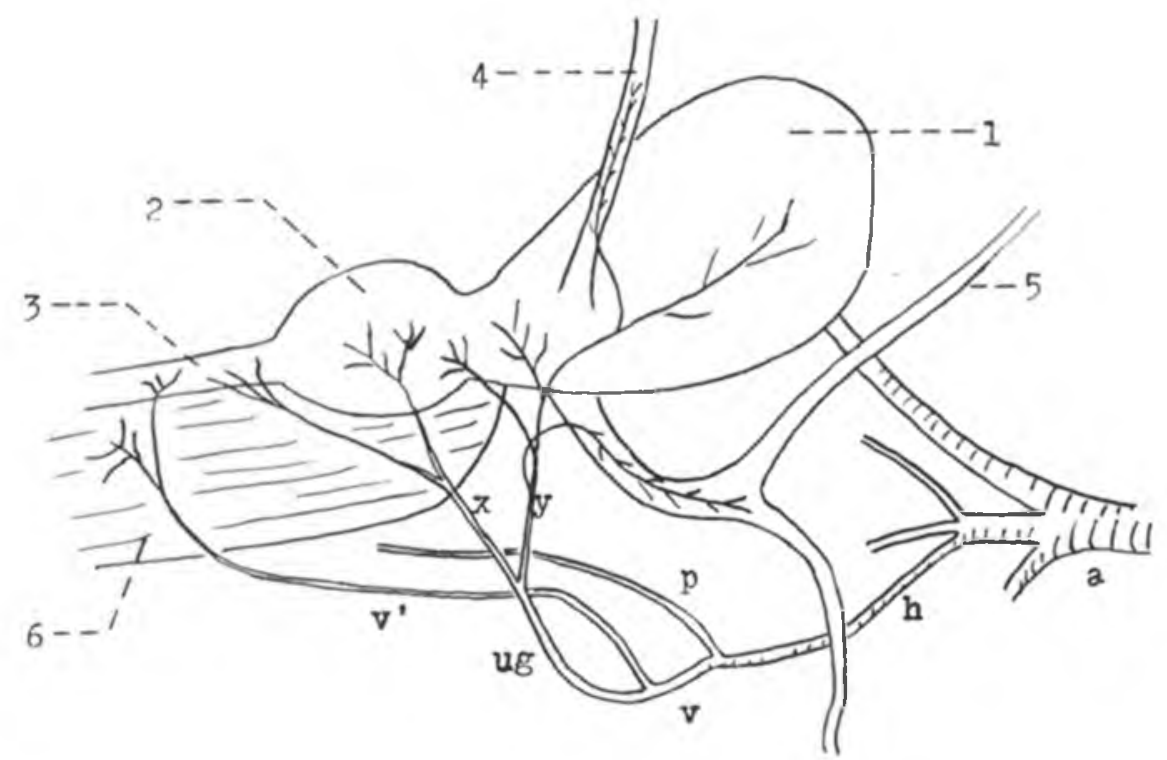

FIGURA 3

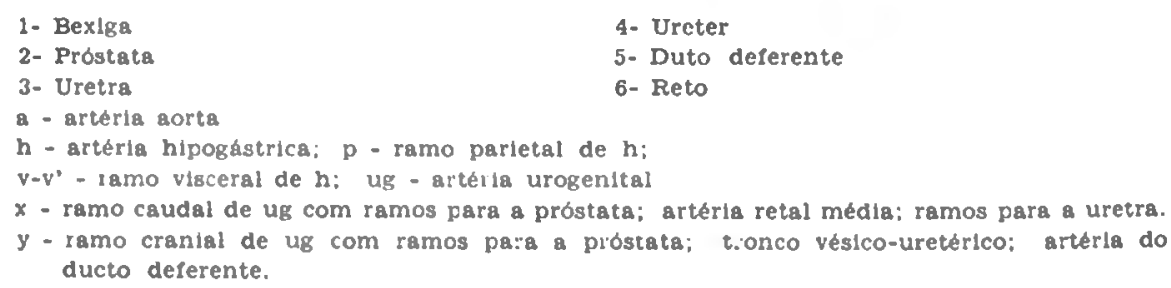

A a. urogenital, por sua vez, subdivide-se em ramo cranial e caudal, destinando-se, o primeiro, à próstata, ao duto deferente e apresentando, ainda, um tronco vésico-uretérico; o ramo caudal dirige-se à próstata, reto (a. retal média) e uretra. cranial.

A a. umbilical continua-se sôbre a bexiga como a. vesical

Como apresentação incomum (fig. 4) a artéria umbilical, permeável e bilateralmente presente, é continuação direta da artéria urogenital, após haver emitido as aa. vesicais craniais. A a. umbilical, neste caso, subdivide-se em a. uretérica, vesical caudal, a. do duto deferente e envia ramos para a próstata e uretra. 


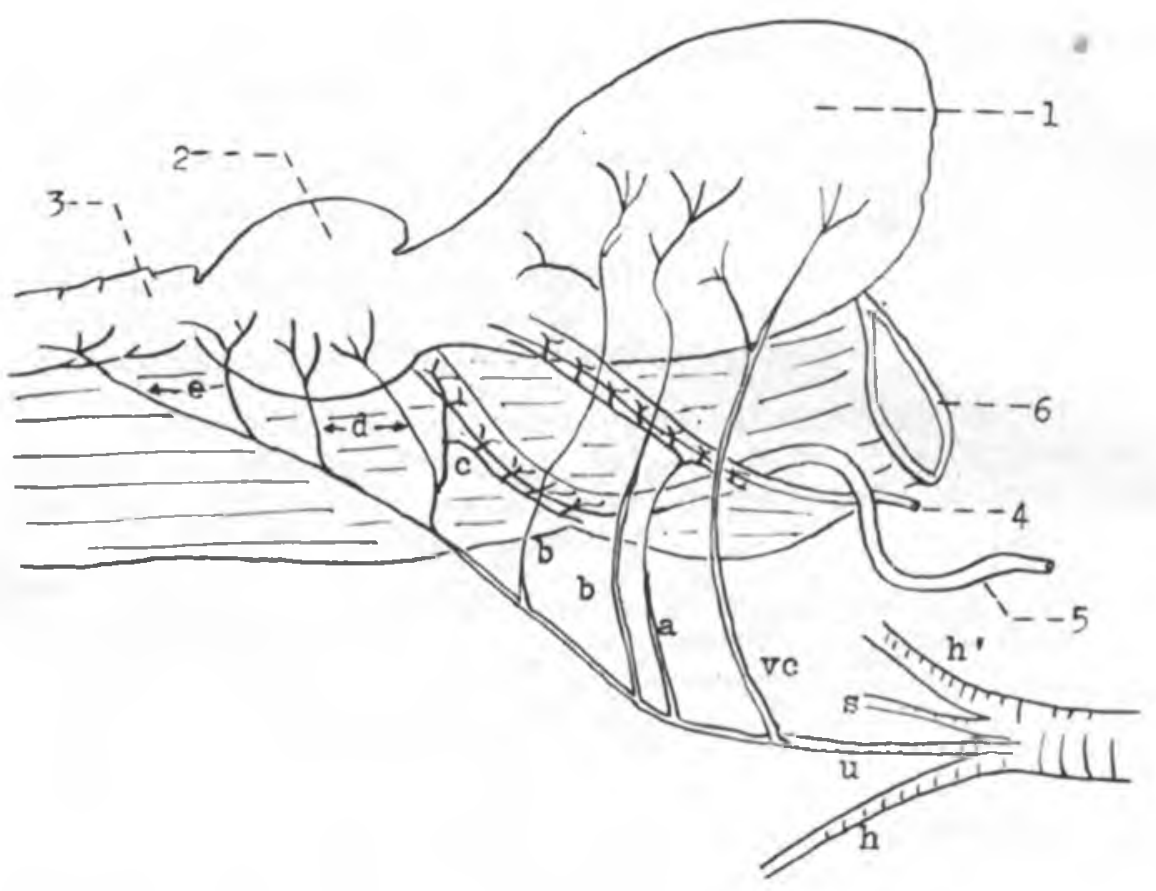

$$
\begin{aligned}
& \text { 1- Bexiga } \\
& \text { 2- Próstats } \\
& \text { 3- Uretra }
\end{aligned}
$$$$
\text { 4- Ureter }
$$$$
\text { 5- Duto deferente }
$$$$
\text { 6- Reto }
$$

h-h' - arterias hipogástricas

B - artéria sacral mediana

u - artéria umbllical

vc - artérla vesical cranial

a - artéria uretérica; b-b - artérias vesicals caudals; c - artéria do duto deferente;

d - ramos para a próstata; e - ramos para a uretra.

Aponta, ainda, em ambos os casos, a artéria vesical ventral que, quando presente, vasculariza o tecido adiposo peri-vesical e a parede da bexiga enviando, excepcionalmente, ramos para a próstata e uretra.

O suprimento nervoso da área, segundo GORDON (1960) está intimamente ligado ao sanguíneo.

O nervo hipogástrico, simpático, origina-se no gânglio mesentérico caudal, podendo ser observado no ligamento umbilical lateral, acompanhado sempre por fino ramo da artéria prostática vesical, terminando medialmente à artéria urogenital ao nível da próstata, onde emite diversos ramos. 
O nervo pélvico, parassimpático, pode ser simples ou duplo. Nasce do $2 .^{\circ}$ nervo sacro, podendo, também, receber fibras do $1 .^{\circ}$ ou 3. nervos e localiza-se entre a artéria e veia urogenital ou caudalmente à primeira. Divide-se em diversos ramos e, juntamente com os do nervo hipogástrico, formam o plexo pélvico, constituído pelo plexo vesical, plexo genital e plexo hemorroidal.

O plexo vesical é formado pelos dois principais troncos correspondentes ao nervo hipogástrico e pélvico que se dirigem à bexiga. O plexo genital envia fibras para a próstata, duto deferente e porção cranial da uretra. O plexo hemorroidal dá filamentos ao reto e uretra pélvica, anastomosando-se com ramos uretrais do nervo pudendo, os quais são constituídos de fibras somáticas e podem ser vistos no terço cranial da próstata e no colo da bexiga.

A cavidade pélvica é continuação direta da cavidade abdominal. SISSON (1933) denomina de linha terminal ao limite entre estas duas regiōes formada, dorsalmente, pelo sacro; lateralmente, pelas linhas iliopectíneas $e$, 'ventralmente, pela borda cranial do púbis.

O peritônio pélvico reveste esta cavidade por distância variável, reflete-se sôbre as vísceras e une um órgão a outro.

MILLER e cols. (1968) afirmam que esta serosa pode ser traçada seguindo-a através de seç̧ão sagital, lateral ao plano mediano, Partindo, ventralmente, ao plano transverso que passa pela tuberosidade iliaca e avançando caudalmente, encontra-se o peritônio sôbre a bainha do músculo reto do abdômen e, logo a seguir, sôbre a região ventral da entrada pélvica, penetrando na cavidade homônima. Reflete-se sôbre a região ventral da bexiga e próstata, no macho, formando um fundo de saco pouco pronunciado, denominado de pubovesical; a seguir, recobre a superfície cranial e dorsal da bexiga, deixa a superfície dorsal da próstata, formando a extensão mais caudal do peritônio e reflete-se, cranialmente, sôbre a superficie ventral do reto, formando o fundo de saco retovesical; continua-se, em seguida, sôbre a parede dorsal do reto, atingindo o sacro (fig. 5). 


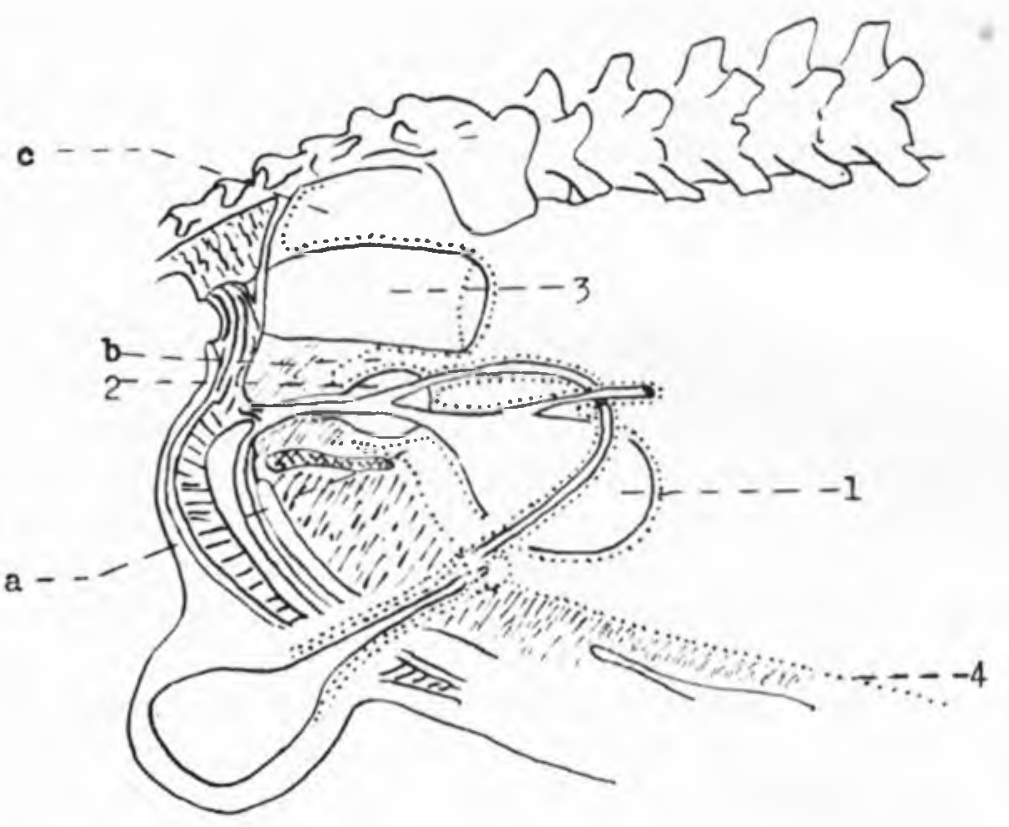

FIGURA 5

1- Bexiga

2- Próstate

3- Reto

4- Pe:itónto (linha pontilhada)

a- lundo de saco puhovesical

b- fundo de saco retovesical

c- fundo de saco sacrorsetal

\section{REVISÃO DA LITERATURA}

Conforme CINOTTI (1948) e O'CONNOR (1950), a hérnia perineal é produzida pelo avanço caudal do conteúdo abdominal através do fundo de saco retovesical, empurrando o peritônio ou, freqüentemente, rupturando-o.

BLAKELY (1957) define o processo como uma falência das estruturas suportadoras da passagem pélvica na contenção dos órgãos pelvianos, ocorrendo, geralmente, na última metade da vida e, de acôrảo com PETTIT (1962), o deslocamento das vísceras ocorre ao longo da linha de menôr resistência, isto é, entre o músculo esfincter externo do ânus e o músculo coccigeo medial, determinando saliência entre o ânus e a tuberosidade isquiática.

ELLETT \& ARCHIBALD (1965) distinguem a hérnia perineal dos outros tipos de hérnias porque, na quase totalidade dos casos, 
o conteúdo não está encerrado em saco peritonial e mesmo se estiver presente, é extremamente delgado e degenerado, fato já salientado por MOLTZEN-NIELSEN (1953) que assevera não encontrar saco herniário pròpriamente dito, mas que a aponevrose, pélvica, as vêzes, pode substituí-lo.

A hérnia perineal pode localizar-se no lado direito, esquerdo ou em ambos os lados do ânus (GARBUTT - 1938). Entretanto, BLAKELY (1957) afirma que na maioria dos casos ela é unilateral, interessando indiferentemente o lado direito ou esquerdo $e$, ocasionalmente, quando da ocorrência de hérnia bilateral, talvez poder-se-ia dizer que estaria localizada centralmente, determinando deslocação caudal do ânus e aumento de volume igual em ambos os lados. Todavia, PETTIT (1962) encontrou condição bilateral em, aproximadamente, metade de seus casos.

ELLETT \& ARCHIBALD (1965) chamam a atenção, ainda, para o fato de que, algumas vêzes, o aumento de volume pode ser evidente em apenas um dos lados e, contudo, cuidadosa palpação revelará fragilidade do diafragma pélvico do outro lado. Lembram, igualmente. que o processo poderá migrar ventralmente ao ânus, atingir a área oposta e determinar aparência de bilateralidade.

Verifica-se na literatura consultada que, apesar do conteúdo herniário ser apontado como variável, diversos autores indicam a bexiga e próstata. como frequientemente envolvidas (O'CONNOR 1950; ELI.ETT \& ARCHIBALD - 1965 e LEONARD - 1968), ainda cue outros órgãos, juntamente com os anteriormente citados, possam integrar o conteúdo, como omento e alças intestinais (SPARKS - 1933; GARPUTT - 1938; HERMANN - 1940; THAYER 1948: MC CUNN — 1953 e ORMROD - 1966), epiploo (CINOTTI - 1948) e tecido adiposo (MOLTZEN-NIELSEN - 1953; BLAKELY - 1957 e PETTIT - 1962).

A ocorrência da condição parece restrita aos machos, muito embora tenha sido mencionada em cadelas (MENSA - 1950).

MOLTZEN-NIELSEN (1953) atribui a uois fatôres a não observância do processo em fêmeas: nestáas, o músculo elevador do ânus é mais desenvolvido e a cavidade peritonial localizada mais cranialmente na pelve, acima do acetábuio.

BLAKELY (1957), a êste respeito, observa que os casos descritos na literatura falham em não revelar dados mais precisos bem como investigação mais pormenorizada.

Todavia, PETTIT (1960) relata ocorrência de hérnia perineal em cadela, constatada após minucioso exame e posterior tratamento cirúrgico de cujo conteúdo herniário participavam o corno uterino 
direito, ligamento largo do útero, omento, alças intestinais e por onde podia, ainda, divisar a bexiga.

No entanto, ORMROD (1966) lembra descrições na literatura de dois casos em cadelas que nada mais eram que hérnias inguinais atípicas, estendendo-se caudalmente e determinando aumento de volume lateralmente a vulva.

A condição de que a ocorrência é sobretudo em animais idosos está confirmada pela maioria dos autores, ainda que possa ser observada em cães jovens (PETTIT - 1962). BLAKELY (1957) aponta-a como, usualmente, ocorrendo na última metade da vida do cão e ELLETT \& ARCHIBALD (1965) observa-a, comumente, em pacientes com mais de oito anos de idade.

Os fatôres etiológicos da hérnia perineal são, ainda hoje, discutidos, não havendo unanimidade de opinião acêrca de sua etiologia.

Em 1908, GUTMANN descreve a afecção, apontando, como causa, movimentos bruscos dos membros posteriores do animal, assim como saltos e trações excessivas. HACKL (1920) inculpa, como fator causal, a atrofia do músculo elevador do ânus e MöLLER \& FRICK (1921) incriminam o aumento da pressão abdominal e fortes trações nos membros posteriores.

A hipertrofia da próstata na etiologia da hérnia perineal foi citada por JAKOB (1924). SPARKS (1935) afirma que êste órgão, quando aumentado de volume, representa parte preponderante na determinação do processo, tornando-se uma cunha móvel que se dirige através da pelve, contribuindo, tambem, no bloqueio da bexiga e acarretando sua distensão; a constipação é associada a êste mecanismo, determinando esforços do animal ao defecar. Opiniōes semelhantes foram externadas por GARBUTT (1938) e HFRMANN (1940).

A manifestação do síndrome coprostase relacionada ao aumento de volume da glândula prostática já havia sido mencionada por LAMY, em 1931, esclarecendo que êste órgão repousa sôbre porção anterior do púbis em plano inextensivel e que todo aumento de volume do mesmo far-se-á, então ,principalmente, em direção dorsal, deslocando o reto. GADD (1944), reexaminando seus conceitos a êste respeito, afirma que a hipertrofia da próstata resulta em compressão do reto acompanhada de estreitamento do mesmo.

A disposição congênita por profundidade anormal do fundo de saco retovesical e maior amplitude da pelve foi lembrada por CINOTTI (1948); entretanto, acredita que a hérnia perineal encontra ampla justificação no aumento da pressão intra-abdominal por 
esforços expulsivos como soe acontecer em cães machos, na constipação e hipertrofia da próstata.

BRUMLEY (1948) julga como fator causal da hérnia, o andar em posição bipedal sôbre os membros posteriores como fazem os cães amestrados.

MORNET (1949) ao incriminar o obstáculo prostático como causa determinante de constipação, explica que a próstata hipertrofiando-se, progressivamente desloca o reto e o comprime contra o sacro resultando, dêste modo, sério impecilho ao trânsito intestinal. Sob ação de esforços expulsivos provocados pela coprostase, os músculos e fascia perineal se enfraquecem e a bexiga comprime o fundo de saco seroso retovesical. Esta escavação acentuando-se, a bexiga ai se aloja inteiramente, arrastando, frequientemente, alcas intestinais e epiploo, provocando uma hérnia perineal.

MOLTZFN-NIELSEN (1953) baseando-se em pesquisas anatômicas e nas observações concernentes à operação de correção, estima que a condição primária de formação é uma ruptura parcial ou total do diafragma pélvico (músculo elevador do ânus), relativamente fraco no macho.

DE VITA (1957) atribui, como fatôres freqüentemente responsáveis pela condição, a pređisposição anatômica congênita ou adquirida e o desequilibrio hormonal. Cita, como predispostas, raças de cães que possuem cauda rudimentar ass ociada a relativa fragilidade do musculo coccígeo. Discutindo o caráter hormonal com efeitos sôbre as estruturas da pelve, lembra que grande parte das hérnias perineais está associada a tumores testiculares ou prostáticos ou, ainda, seus portadores exibem sinais de desequilíbrio endócrino. Todavia, conclui que nem todos os animais apresentando êstes sintomas desenvolvem hérnia perineal.

A êste respeito, PUNTONI (1957a) admite que a gênese hormonal ligada a uma disendocrinia não está provada pelo menos no que concerne à ação exclusiva e direta sôbre o diafragma pélvico.

ROSSNER (1958) presume que haja conexão etiológica entre hipertrofia prostática e casos de hérnia perineal, pois aquela condição foi observada em $80^{\text {\% }}$ ' dos mesmos.

Entretanto, ORMROD (1966) considera existirem diversos fatôres cue, atuando em combinação, são responsáveis pela ruptura do diafragma pélvico a qual é causa imediata da doença.

Desde há muito, os vários autores que estudaram a hẻrnia perineal tentam encontrar a melhor técnica para o tratamento ci- 
rúrgico da afecção devido ao fato de que, em muitos casos, observou-se o retôrno do processo.

Já em 1926, CADIOT preconizava incisão cutânea vertical sôbre a hérnia, liberação dos órgãós herniados e posterior redução, seguindo-se a ligadura do saco e sua excisão. Realizava, também, a cistopexia ou retopexia, conforme a necessidade.

SPARKS (1933) para fechamento da abertura herniária utiliza a fascia perineal e outros tecidos para assegurar o suporte das suturas.

FORSSELL (1937), após incisão prẻvia da pele e redução do conteúdo, fecha o anel herniário com diversas linhas de sutura, sendo que cada uma delas sepulta a precedente, obtendo, desta maneira, sucesso em oito de dez casos operados.

GARBUTT (1938) pondera que bons resultados podem ser esperados da operação se o paciente não fôr muito idoso e a abertura herniária não muito extensa.

HERMANN (1940) também preconiza o ancoramento da bexiga e colon à parede abdominal com prévia redução cirúrgica do conteúdo.

Após a laparotomia pré-púbica, EYESTONE (1941) traciona a bexiga e une seus ligamentos por sutura, visando fechamento parcial do fundo de saco pelo qual êste órgão desloca-se; realiza, da mesma forma, a retopexia e cistopexia.

CINOTTI (1948), realizada a dissecção do saco herniário e torção para esvaziá-lo, resseca sua porção exuberante e fixa o côto no ligamento sacro-isquiático.

MITCHEIL (1948) emprega no fechamento da abertura herniária três fileiras de suturas, sobrepondo-as umas as outras.

Considerando a utilidade da fascia perineal, HENDERSON (1949) emprega-a como suporte das suturas.

Apontando como insatisfatório todo e qualquer tratamento médico, O'CONNOR (1950) afirma que a operação radical proporciona a única oportunidade de cura, sendo, entretanto, frequientemente impraticável devido à ausência de saco peritonial para ser ligado e, dêste modo, obliterar a cavidade. MC CUNN (1953) prefere não intervir cirurgicamente se o animal não estiver em perigo de vida aparente, concluindo ser difícil a recuperação devido à amplitude do orifício herniário e a inacessibilidade das regiões mais profundas da pelve. 
MOLTZEN-NIELSEN (1953), em 17 casos de hérnia perineal, executa plástica muscular através de incisão semi-circular ao redor do ânus com finalidade de liberar o músculo esfincter anal, suturando sua borda no músculo coccígeo e ligamento sacro--isquiático, obtendo êxito em 14 casos.

Resultados desfavoráveis em decorrência da falta de conhecimentos anatômicos e da má colocação da primeira linha de sutura foram ressaltados por MEULLER (1954), recomendando para a herniorrafia, o aproveitamento dos músculos coccígeo, obturador e esfincter anal, juntamente com a fascia perineal.

BLAKELY, em 1957, salienta dois pontos básicos para obtenção de sucesso na cirurgia: acurada restauração da anatomia normal da região e correção dos fatôres que determinam o processo. Afirma, ainda, que as dificuldades encontradas durante a operação podem ser devidas a exposição inadequada das estruturas envolvidas na afecção. Sua técnica consiste em: incisão ligciramente curva da pele sôbre a hérnia; dissecção digital identificando cavidade e conteúdo herniários; redução do mesmo. Reconstrói o diafragma pélvico, suturando a margem anterior do músculo esfincter externo do ânus ao músculo coccígeo lateral, ligamento sacro-isquiático e músculo obturador interno; em um segundo plano, a margem lateral da fascia perineal é superposta a primeira linha de sutura e a margem medial prêsa à porção posterior do esfincter externo do ânus.

PUNTONI (1957a) aproveita para as suturas, formações aponevróticas e musculares, reforçando-as pela união da margem média-superior do músculo coccígeo ao contôrno do esfincter anal externo, superpondo-o, parcialmente, na abertura. Em seguida, o limbo medial da fascia é suturado no ligamento sacro-isquiático e o limbo lateral unido ao músculo esfincter externo do ânus.

Em um caso de hérnia perineal associada a diverticulo retal, PUNTONI (1957b) utiliza o tecido conjuntivo presente para suturá-lo à parede retal como refôrço. Após, com auxílio do músculo coccígeo lateral, limbo medial e lateral da fascia perineal, promove tripla imbricação, visando reforçar o fechamento.

PETTIT (1962), em estudo de 40 cães, emprega o tratamento cirúrgico apontado por BLAKELY (1957). Salienta, outrossim, ser desnecessária a cirurgia para a correção do divertículo retal que, ocasionalmente, ocorre, pois a reconstrução dos planos permite suporte suficiente na prevenção de dilatação posterior e conseqüente retenção de fezes.

A reconstrução do diafragma pélvico como principal objetivo da operação foi, também, ressaltada por ELLETT \& ARCHIBALD 
(1965) que acreditam, entretanto, ser impossivel a reparação total em decorrência do rompimento ou atrofia dos músculos envolvidos, considerando de importância o músculo esfincter externo do ânus pois, é a única estrutura do lado medial onde as suturas podem ser inseridas.

ORMROD (1966) afirma que o tratamento cirúrgico dá excelentes resultados na maioria dos casos e descreve técnica semelhante a de PUNTONI (1957a).

LEONARD (1968) chama atenção para a identificação das estruturas que compõem a abertura herniária, comentando que, se tôdas forem individualizadas, o fechamento não será difícil. No entanto, salienta que, freqüentemente, o músculo coccígeo está atrofiado, devendo-se, nestes casos, aproveitar todo tecido útil presente para a sutura. Em uma primeira etapa, une a borda caudal dos músculos coccígeo e elevador do ânus à porção cranial do músculo esfincter externo do ânus, aproveitando, em seguida, o ligamento sacro-isquiático. A região ventral da abertura é fechada pela sutura da borda cranial do músculo esfincter externo do ânus no músculo obturador interno. Afirma que o fechamento poderá ser aperfeiçoado pelo aproveitamento da fascia perineal, unindo-a sôbre a primeira linha de sutura. A pele, retirado o excesso, é reunida em pontos separados simples.

Nas hérnias perineais bilaterais, BLAKELY (1957) recomenda a operação em duas etapas, sendo que o intervalo de tempo é, geralmente, de duas semanas.

Atenta para o fato de que, cêrca da junção do terço médio e inferior da parede da abertura herniária, há uma faixa que se estende da parede pélvica em direção ao reto onde estão contidos os suprimentos sanguíneos nervosos do órgão e sua preservação é necessária na reparação do processo bilateral, pelo menos em um dos lados, pois destruição intencional ou acidental $\mathrm{em}$ ambos os lados, resultará em paralisia do esfincter anal e conseqüente incontinência fecal.

BERGE \& WESTHUES (1961) e PETTIT (1962), entretanto, aconselham o reparo simultâneo da hérnia perineal bilateral.

A castração ou utilização de hormônios estrógenos objetivando diminuição de volume da próstata é aconselhada e empregada como tratamento suplementar da hérnia perineal.

Em 1932, SCHLOTTHAUER ressalta que os testículos são essenciais ao normal desenvolvimento da próstata e que a castração embarga seu crescimento, citando HOBDAY (1924) que, por êste meio, obteve bons resultados na hipertrofia dêste órgão. GARBUTT (1938) aconselha sua prática em adição à operação radical da hér- 
nia perineal e HERMANN (1940) a utiliza. Entretanto, CINOTTI (1952) considera-a impraticável em cães reprodutores.

BLAKELY (1957) nos casos em que realizou a hermiorrafia sem orquiectomia, observou, após algum tempo, recidiva do processo, acreditando, então, ser necessária a castração.

DE VITA (1957) concorda plenamente com o autor precedente, afirmando que a orcuiectomia deveria ser realizada em todos os casos de hérnia perineal como primeiro passo para sua correção e PETTIT (1962) aceita seu valor na prevençäo de recidivas, apenas quando houver comprometimento prostático.

A utilização de estrógenos no tratamento da hipertrofia prostática canina foi realçada por JULIAN, em 1947.

THA YER (1948), devido a idade e condições gerais do paciente, preferiu a administração de hormônios estrógenos à castração, após correção cirúrgica da hérnia perineal.

MORNET (1949), nas afecções prostáticas também prefere êste tratamento, pois permite contrabalançar a atividade de todos os centros andrógenos.

MATERA \& ARCHIBALD (1965) afirmam que a administração de hormônios estrogênicos a.tuando na depressão da secreção glandular da próstata diminuindo seu tamanho, já foi plenamente demonstrada. No entanto, consideram que superdosagens por tempo prolongado podem acarretar metaplasias dos dutos e desenvolvimento da musculatura intersticial lisa e do tecido fibroso, determinando aumento de volume do órgão.

A prostatectomia como tratamento coadjuvante da hérnia perineal foi, pela primeira vez, realizada por SPARKS, em 1933, baseado em suas próprias observações de que não haveria restabelecimento permanente sem a remoção da principal causa, procurando retirar a próstata com incisões de ambos os lados da glândula, assegurando, dêste modo, a integridade da uretra.

GADD (1944) salienta que a oportunidade de sucesso na cirurgia é grandemente diminuída sem a correção da condição patológica da próstata. Pratica, em primeiro lugar, a operação dêste órgão, com incisão em cada lado do mesmo, atingindo cápsula e estruturas subjacentes através de laparotomia pré-púbica. Em um segundo tempo, corrige a hérnia.

Coube a ARCHIBALD \& CAWLEY (1961) realizarem o tratamento cirúrgico em um caso de hérnia perineal com prostatectomia total por esta mesma via de acesso, utilizando a técnica de MATERA (1952). 
Grande progresso alcançou a cirurgia prostática com os trabalhos de MATERA (1952) para remoção da próstata pela via perineal no cão, sendo a glândula retirada totalmente, com ampla visualização, contrôle seguro da hemorragia e resultados funcionais satisfatórios. Anteriormente, com exceção de alguns trabalhos como os de LAMY (1931) e SCHLOTTHAUFR (1937), a prostatectomia ou mesmo a prostatotomia eram consideradas como operações difíceis e expostas a complicações (CADIOT \& ALMY - 1924), gravíssimas e extremamente delicadas (CINOTTI - 1948), impraticáveis e impossíveis (O'CONNOR - 1950 e MENSA - 1950.

\section{MATERIAL E METODO}

Constam do presente estudo, 10 cães apresentados para exame no Ambulatório de Clínica do Departamento de Patologia e Clínicas Cirúrgica e Obstétrica da Faculdade de Medicina Veterinária e Zootecnia da Universidade de São Paulo, portadores de hérnia perineal, constatando-se a presença de bexiga e próstata como integrantes co ccnteúdo herniário.

Os cães eram de diferentes raças, com idade variando entre 7 a 14 anos, 5 dos quais apresentavam o processo do lado direito, 4 do lado esquerdo do períneo e constatando-se em apenas 1 animal, a condição bilateral da hẻrnia, conforme observação dos protocolos.

Seguimos, em nossas observações, plano operatório comum a tôdas as intervenções, ou seja: pré-operatório, anestesia, atitude no ato operatório, técnica operatória e pós-operatório.

1 - Pré-operatório. Um dos principais fatôres no progresso da cirurgia é, sem dúvida, os cuidados pré-operatórios destinados à melhoria das condições gerais do paciente, bem como reduzir as possibilidades de infecção e facilitar a técnıca adotada.

Para os cães de nossas observações, procuramos estabelecer orientação própria, além dos cuidados pré-operatórios comuns a tôdas as intervençōes cirúrgicas já bem estabelecidos nos compêndios de técnica cirúrgica visando preparar o paciente, favorecendo o ato cirúrgico e pós-operatório livre de complicaçōes. 'Dêste modo, realizamos:

Exame da próstata pelo reto. Procuramos determinar seu tamanho e grau de deslocamento.

Cateterismo vesical. Com o deslocamento da bexiga na pelve e conseqüente oclusão da uretra, freqüentemente, o animal apresenta dificuldade ou mesmo impossibilidade de micção. $O$ cateterismo 
vesical era praticado tantas vêzes quantas necessárias, evitando-se, assim, retenção urinária e instalação de estado urêmico.

Exame dos aparelhos cárdio-vascular e respiratório. Sendo afecção de ocorrência, sobretudo, em cães com idade avançada e frequientemente portadores de lesões cardíacas ou respiratórias, dávamos especial atenção a êstes aparelhos, a fim de colocar o animal em condições de suportar o traumatismo operatório.

Administração de fluidos intravenosos, plasma ou sangue total quando de animais debilitados e com más condições gerais, visando, principalmente, manter o equilibrio ácido-básico do organismo.

Aplicação de enemas ou laxativos com finalidade de exonerar o conteúdo retal, muitas vêzes retido, determinando dificuldade na defecação.

Restrição alimentar, pelo menos, de 12 a 18 horas antes da cirurgia.

Lavagem retal no dia da operação com sonda de borracha e utilização de solução oleosa.

2 - Anestesia. Preferimos, em todos os nossos casos, a anestesia geral por inalação, em máscara de circuito semi-fechado, utilizando como anestésico a mistura éter-oxigênio.

Administrávamos, prèviamente, 40 a 50 minutos antes do início da cirurgia, pela via subcutânea, um tranqüilizante - cloridrato de clorpromazina * - na dose de, aproximadamente, $1 \mathrm{mg}$ por quilograma de pêso.

3 - Atitude no ato operatório. Os animais foram contidos em decúbito dorsal, em posição de declive e com os membros posteriores tracionados cranialmente, colocando-nos de fronte à região perineal.

4 - Técnica operatória. Realizamos, em conjunto com a reparação da hérnia, a prostatectomia, já que nos casos aqui catalogados, a próstata estava envolvida no processo.

Como passo inicial e preliminar, uma sonda de calibre variável era introduzida através da uretra, alcançando a bexiga.

1. tempo: - Incisão da pele e tecido celular subcutâneo. Incisão ligeiramente oblíqua da pele era praticada sôbre a formação herniária, de comprimento adequado, iniciando-se ao lado do ânus junto à inserção da cauda e prolongando-se em direção à tuberosidade isquiática.

- AMPLICTIL - Rhodis - Indústrias Quimicas e Téxtels S.A. 
Pela seç̧ão de pequenos ramos da artéra perineal e veias du. rante a abertura do tecido celular subcutâneo, a hemostasia era praticada incontinente.

Geralmente não encontramos saco herniário, entrando-se em contato direto com 'o conteúdo da hérnia; todavia, não pudemos precisar da sua inexistência ou, se o mesmo, devido a pouca espessura, fôra rompido quando da realização da diérese.

Realizamos, a seguir, introdução e recolocação na cavidade abdominal de outros órgãos que, eventualmente, eram constituintes do conteúdo herniário

2. tempo: - Exposição da próstata. Por tração moderada da bexiga, a glândula prostática era deslocada até a abertura cutânea, manobra relativamente fácil, apesar de seu aumento de volume.

3. tempo: - Prostatectomia. Utilizamos, para remoção da próstata, a técnica preconizada por MATERA, em 1952.

Procedemos a secção da porção caudal da uretra prostática, expondo-se o cateter, após dissecá-la da porção distal da próstata, procurando, dêste modo, poupá-la o quanto possivel (fig. 6).

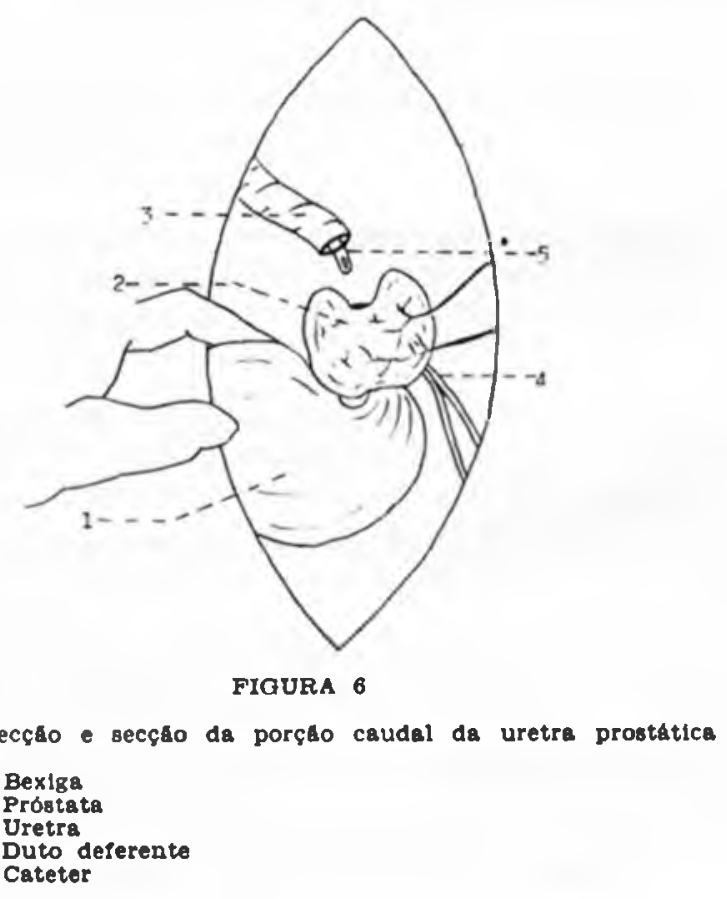


Identificamos e efetuamos a ligadura dos ramos arteriais prostáticos; logo a seguir, era realizada manobra semelhante para os canais deferentes (fig. 7).

Da mesma maneira, realizamos a dissecção da uretra na porção cranial da próstata, evitando-se, após sua secção, a lesão do esfincter vesical e obtendo-se, com êste procedimento, diâmetros uretrais pràticamente iguais e coaptação perfeita das secções de modo a permitir a posterior reconstituição uretral (fig. 7).

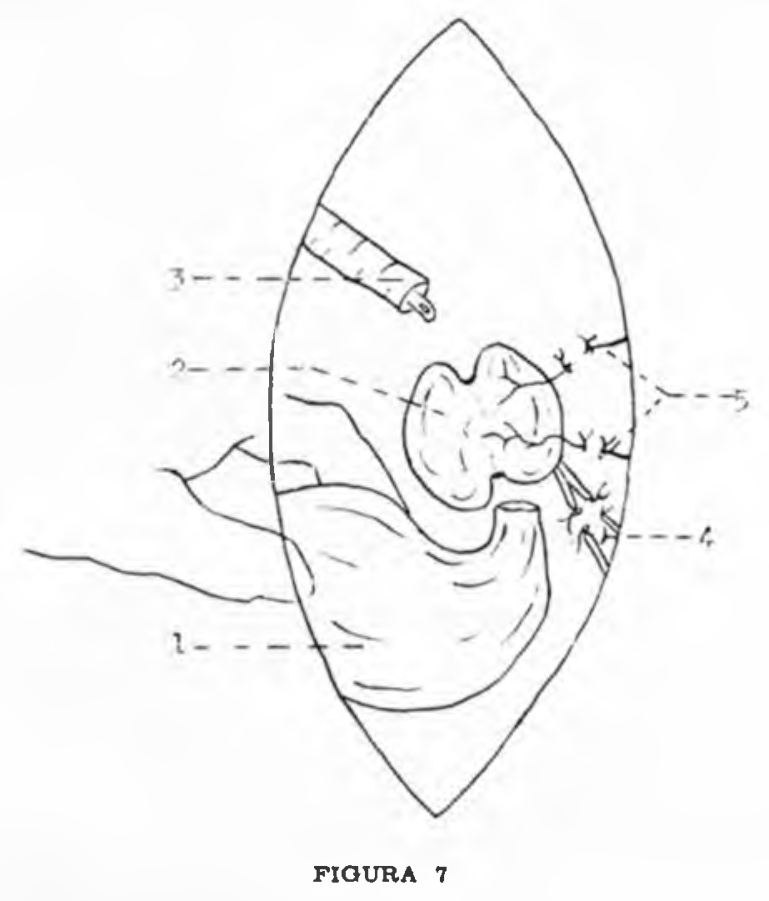

Dissecçío e secçáo da porçâo proximal da uretra prostática. Ligadura dos vasobs prostáticos e dutos deferentes

1 - Bexiga
2 - Prostata
3 - Uretra

4 - Dutos deferentes

5 -.Vasos prostáticos

Referendadas as secções proximal e distal da uretra e com a recolocação do cateter na secção proximal, efetuamos anastomose uretro-uretral por sutura em pontos separados simples com fio de algodão $\mathrm{N}^{\circ} 00$ montado em agulha atraumática (fig. 8). 


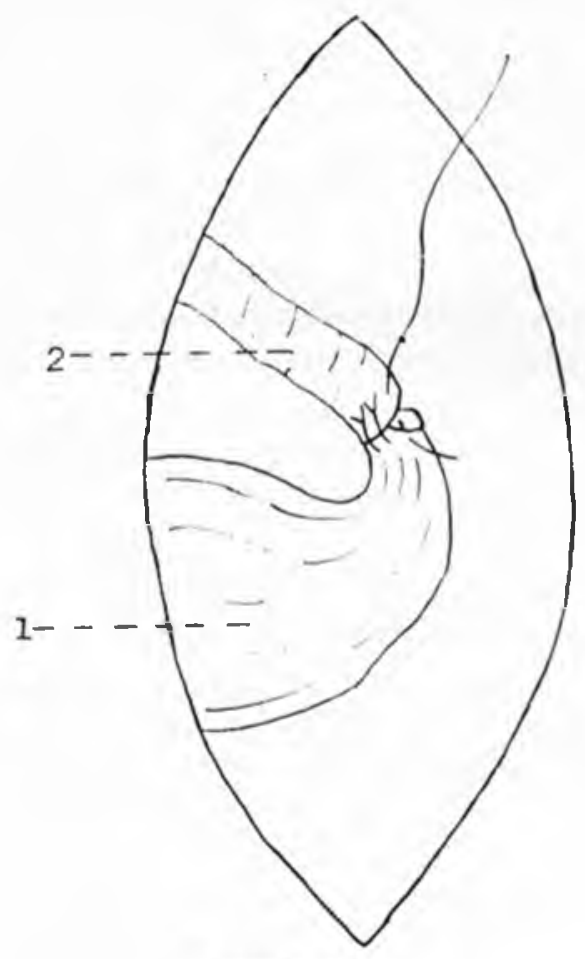

FIGURA 8

Anastomose uretro-uretral

4. tempo: - Herniorrafia. Com a recondução da bexiga para a cavidade abdominal, iniciamos o fechamento da abertura herniária.

Sendo a músculo esfincter externo do ânus a única estrutura do lado medial onde as suturas podem ser inseridas, identificávamos, lateralmente a abertura, o músculo coccígeo, ligamento sacro-isquiátrico e músculo obturador interno.

A sutura entre os músculos esfincter externo do ânus e coccígeo era iniciada na região dorsal da abertura por meio de pontos separados simples com fio de algodão, colocados a uma distância adequada, procurando-se reconstruir o diafragma pélvico (fig. 9). 


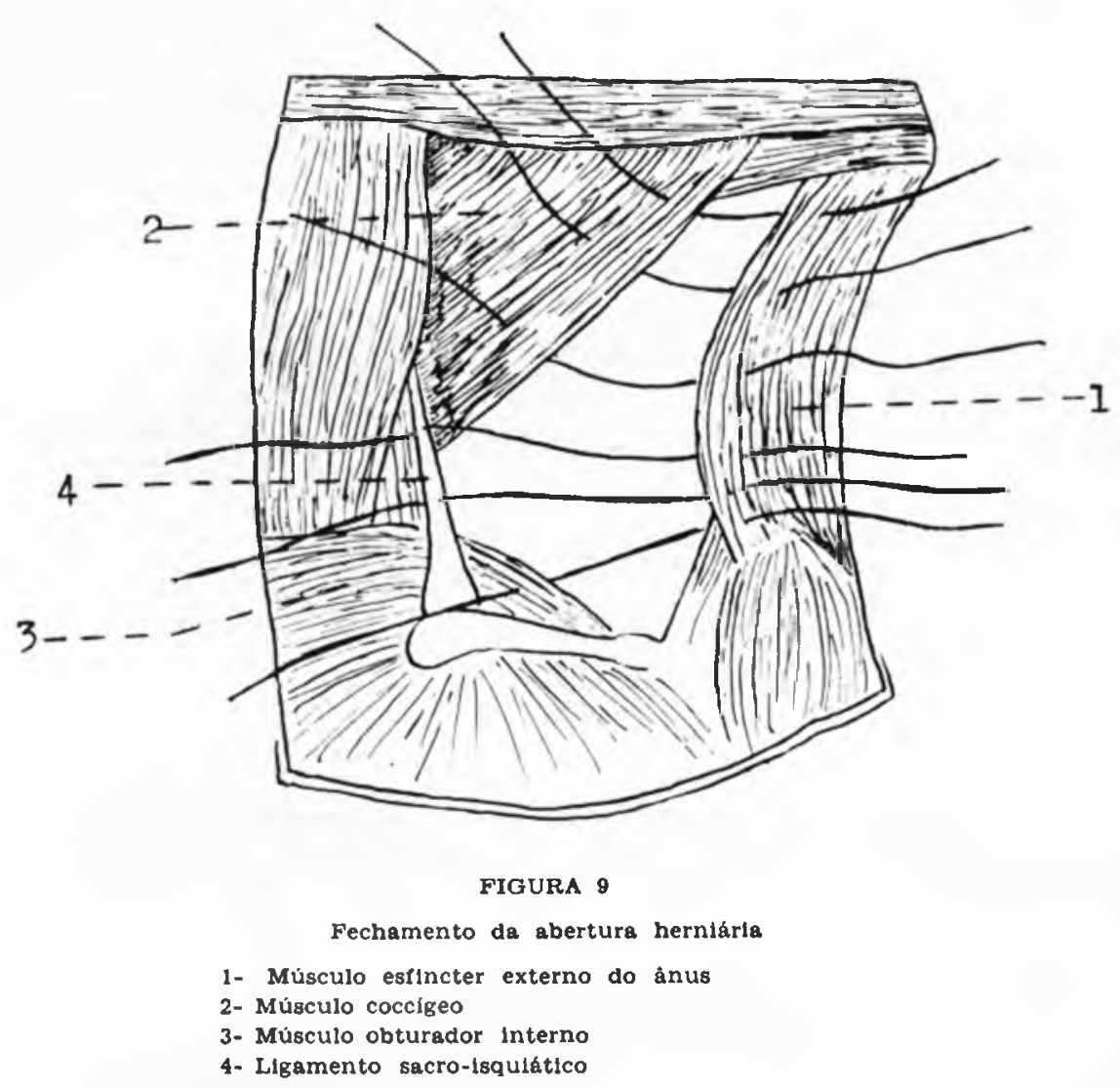

Freqüentemente, não podíamos nos valer do músculo coccíg€o na região látero-ventral da abertura; recorriamos, então, ao ligamento sacro-isquiático e músculo obturador interno que eram do mesmo modo suturados ao músculo esfincter externo do ânus (fig. 9).

Para facilidade de técnica, todos os pontos eram passados e os cabos dos fios reunidos e presos por pinças de Kelly; realizávamos, em continuação, o fechamento da porta herniária pela tração gradativa e aplicação dos nós que eram iniciadas pelo primeiro ponto colocado e, assim, sucessivamente, até o último.

A seguir, em um segundo plano, utilizamos a fascia perineal, dissecada de ambos os lados da abertura, unindo-a sôbre a primeira linha de sutura (fig. 10). 


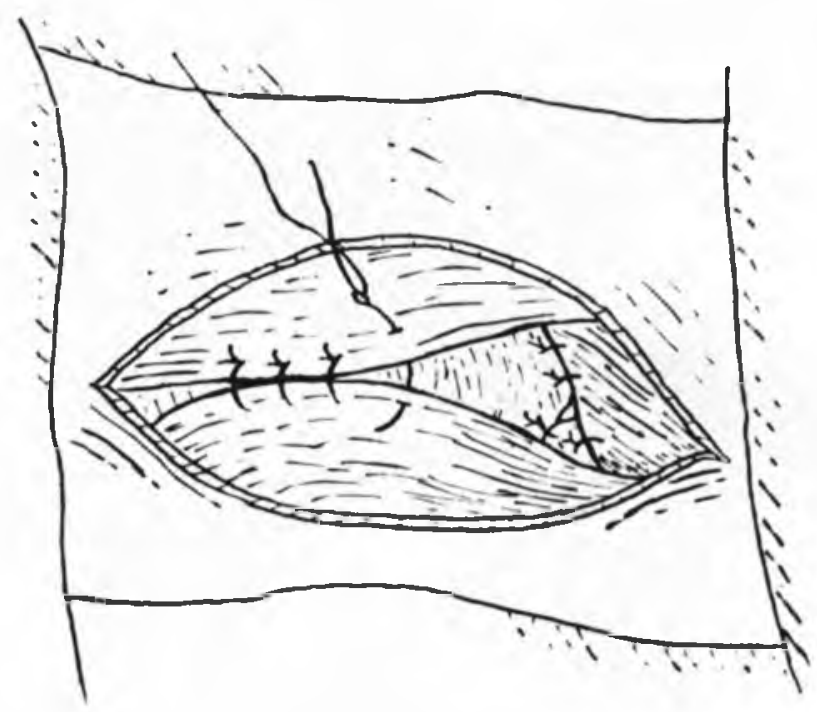

FIGURA 10

5. ${ }^{\circ}$ tempo: - Fechamento da pele. Suturamos a incisão cutânea, retirando o excesso de pele, se necessário, em pontos separados simples com fio de algodão (fig. 11).

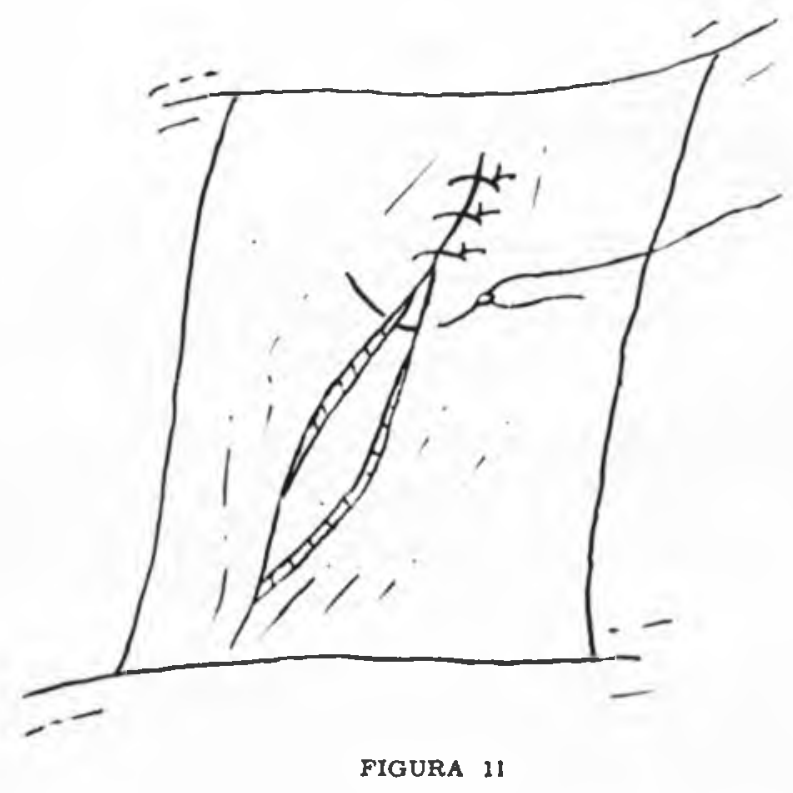


O cateter uretral era fixado à glande por meio de um ponto simples.

5 - Pós-operatório. Logo após o término da operação, a ferida operatória era protegida por meio de curativo sêco com gaze esterilizada, prêso com largas faixas de esparadrapo, impedindo, assim, que o paciente atingisse a ferida e prevenindo o risco de infeç̧ão por contaminação tão freqüente na região perineal. Êste curativo era renovado 24 horas após o ato cirúrgico.

Eram administrados alimentos líquidos durante três dias e após, alimentos semi-sólidos até a retirada dos pontos. Aconselhávamos, ainda, laxativos leves. Antibióticos e quimioterápicos eram aplicados, sistemàticamente.

De acôrdo com o caráter de cada animal, indicávamos a administração de drogas tranqüilizantes.

O cateter uretral era retirado no $4 .^{\circ}$ ou $5 .^{\circ}$ dia do pós-operatório e a sutura cutânea removida após uma semana.

\section{RESULTADOS}

Dos dez animais operados, sete receberam alta por cura com a retirada dos pontos cutâneos, uma semana após a operação (protocolos n. ${ }^{\circ} \mathrm{s} 1,3,5,6,7,8$ e 10).

Um dos animais (protocolo $n^{\circ} 2$ ), com a retirada do cateter uretral, apresentou incontinência urinária durante os seis dias subseqüentes que entretanto, desapareceu, voltando à normalidade sem que qualquer tratamento fôsse indicado.

Em dois casos (protocolos n. ${ }^{\circ} \mathrm{s} 4$ e 9 ) houve deiscência parcial dos pontos de sutura da pele, fato que atribuímos infecção da ferida operatória por contaminação fecal, sendo tratadas através da aplicação de antissépticos locais, cicatrizando-se por segunda intenção, decorridos 15 e 18 dias da operação, respectivamente.

Até o presente não foi constatada recidiva ou outras complicações decorrentes da técnica empregada, nos casos constantes dêste estudo.

\section{COMENTĀRIOS}

Não obstante a etiologia da hérnia perineal ser, ainda hoje, discutida, admite-se que as afeç̧ões prostáticas desempenham papel importante no processo, fato já observado por JAKOB (1924), SPARKS (1933), GARBUTT (1938), HERMANN (1940), GADD 
(1944), DE VITA (1957), PUNTONI (1957a), ROSSNER (1958) e ARCHIBALD \& CAWLEY (1961).

Ainda que a castração e a administração de hormônios estrogênicos tenham sido freqüentemente utilizadas nas enfermidades da próstata ou como coadjuvante no tratamento da hérnia perineal (SCHLOTTHAUER - 1932; GARBUTT - 1938; HERMANN - 1940; THAYER - 1948; MORNET - 1949; BLAKELY 1957; DE VITA - 1957 e JUBB \& KENNEDY - 1963) falham, algumas vêzes, não produzindo os efeitos desejados (LORD e cols. - 1956).

Dêste modo, na correção cirúrgica da hérnia perineal, como passo importante na prevenção de recidivas, preferimos e realizamos a ablação da glândula prostática em todos os casos que o órgão apresentava-se aumentado de volume e compunha o conteúdo herniário.

$\mathrm{Na}$ literatura consultada, vemos que apenas SPARKS (1933) e GADD (1944) procuraram abordar a próstata visando sua destruição ou remoção, concomitantemente ao tratamento da hérnia, realizando prostatectomias parciais e ARCHIBALD \& CAWLEY (1961) descreveram, sòmente, um caso de correção da afecção com prostatectomia total pela via perineal.

Para a remoção da próstata nos dez casos constantes dêste trabalho, utilizamos a técnica de MATERA (1952). A asserção de ARCHIBALD \& CAWLEY (1956) de que próstatas grandemente aumentadas de volume não podem ser retiradas pela via perineal, apesar de verdadeira, não se enquadra nos casos por nós estudados, já que tal possibilidade era dirimida quando do exame clínico.

Obedecemos, dentro da técnica, algumas normas que consideramos ser de importância.

Assim, por dissecção, isolamos a porção proximal e distal da uretra junto à prostata com a finalidade de após sua secção, obter-se diâmetros uretrais pràticamente iguais, facilitando notàvelmente a aproximação das secções uretrais e permitindo perfeita anastomose.

Procuramos, também, ligar e seccionar, apenas, os ramos das artérias que se dirigiam à glândula, preservando, assim, a irrigação sanguínea da bexiga e uretra.

Apesar dos diversos autores que trabalharam no assunto preferirem o fio de categute para realização da anastomose uretro-uretral, optamos pelo fio de algodão, calibre $n .^{\circ} 00$, montado em agulha atraumática, devido sua fácil obtenção e poder aquisitivo relativamente baixo em nosso meio. 
Na reparação cirúrgica da hérnia perineal, preocupamos-nos em identificar e aproveitar tôdas as estruturas componentes do processo, visando, dêste modo, restauração anatômica da região, valendo-nos ,ainda, da fascia perineal, elemento útil no suporte das suturas subjacentes.

No caso de hérnia bilateral ,obedecemos a mesma técnica, reparando ambos os lados simultâneamente, o que discorda de BLAKELY (1957) que recomenda a operação em duas etapas.

Quanto às complicações por vêzes observadas no pós-operatório, apenas verificamos um caso de incontinência urinária reversível conforme, aliás, assinala MATERA \& ARCHIBALD (1965).

Deixaremos de fazer maiores comentários a respeito da anestesia utilizada, pois a escolha da mesma deve ficar a critério de cada profissional, de acôrdo com sua experiência e preferência pessoal. Embora ela contribua para o sucesso da operação, não constitui fator preponderante para a técnica operatória.

Nossa preferência pela anestesia geral por inalação, através da mistura éter-oxigênio, após a administração de tranqüìizante, prende-se à segurança ouve oferece bem como à rápida recuperação pósanestésica que oferece.

\section{CONCLUSÕES}

Podemos concluir que:

1 - A técnica de prostatectomia preconizada por MATERA (1952) trouxe contribuição efetiva para o tratamento cirúrgico da hérnia perineal do cão, permitindo obter resultados funcionais satisfatórios.

2 - A utilização de apenas uma única via de acesso para ablação da próstata e correção da hérnia perineal é de real importância, principalmente, em se tratando de pacientes com idade avançada e más condições orgânicas gerais.

3 - A prostatectomia deve ser praticada sempre que a próstata esteja envolvida no processo.

4 - A técnica adotada para a herniorrafia mostrou-se eficaz em todos os casos. 


\section{PROTOCOLO DAS OBSERVAÇÕES}

PROTOCOLO N. 1

1 - Identificação

Raça: - Boxer

Idade: - 11 anos

Pelagem: - Castanha

2 - Exame clínico

Tempo de evolução: - 18 meses

Sintomas: - Aumento de volume na região perineal esquerda.

Dificuldade na defecação e micção. Bexiga e próstata aumentada de volume presentes no conteúdo herniário. Medicado com hormônio estrogênico, sem resultado apreciável.

3 - Operação praticada conforme técnica descrita. por cura.

Retirada dos pontos cutâneos 7 dias após a operação. Alta

\section{PROTOCOLO N. ${ }^{\circ} 2$}

\section{1 - Identificação}

Raça: - Sem raça definida

Idade: -9 anos

Pelagem: - Amarela

2 - Exame clínico

Tempo de evolução: -5 meses

Sintomas: - Aumento de volume na região perineal esquerda.

Dificuldade na micção. Bexiga e próstata aumentada de volume presentes no conteúdo herniário.

3 - Operação praticada conforme técnica descrita.

Incontinência urinária após a retirada do cateter.

Retirada dos pontos cutâneos 7 dias após a operação.

Micção normal 11 dias após a operação. Alta por cura.

\section{PROTOCOLO N. ${ }^{\circ} 3$}

\section{1 - Identificação}

Raça: - Pointer

Idade : -12 anos

Pelagem: - Castanha

2 - Exame clínico

Tempo de evolução: - 12 meses

Sintomas: - Aumento de volume na região perineal direita. Dificuldade na micção. Bexiga e próstata aumentada de volume presentes no conteúdo herniário.

3 - Operação praticada conforme técnica descrita. por cura.

Retirada dos pontos cutâneos 7 dias após a operação. Alta 


\section{PROTOCOLO N. ${ }^{\circ} 4$}

1 - Identificação

Raça: - Sem raça definida

Idade: -7 anos

Pelagem: - Negra

2 - Exame clínico

Tempo de evolução: -3 meses

Sintomas: - Aumento de volume na região perineal direita. Dificuldade na defecação e micção. Bexiga e próstata aumentada det volume presentes no conteúdo herniário.

3 - Operação praticada conforme técnica descrita.

Deiscência parcial dos pontos cutâneos: aplicação de antissépticos locais.

Retirada dos pontos remanescentes 7 dias após a operação.

Cicatrização por segunda intenção decorridos 15 dias da operação. Alta por cura.

\section{PROTOCOLO N. ${ }^{\circ} 5$}

I - Identificação

Raça: - Sem raça definida

Idade: - 14 anos

Pelagem: - Negra

2 - Fxame clínico

Tempo de evolução: -6 meses

Sintomas: - Aumento de volume na região perineal direita. Dificuldade na defecação. Bexiga e próstata aumentada de volume presentes no conteúdo herniário.

3 - Operação praticada conforme técnica descrita.

Retirada dos pontos cutâneos 7 dias após a operação. Alta por cura.

\section{PROTOCOLO N. ${ }^{\circ} 6$}

\section{1 - Identificação}

Raça: - Com sangue Basset

Idade: -9 anos

Pelagem: - Castanha

2 - Exame clínico

Tempo de evolução: - 15 dias

Sintomas: - Aumento de volume na região perineal esquerda. Dificuldade na defecação e micção. Bexiga e próstata aumentada de volume presentes no conteúdo herniário.

3 - Operação praticada conforme técnica descrita. por cura.

Retirada dos pontos cutâneos 7 dias após a operação. Alta 


\section{PROTOCOLO N. ${ }^{\circ} 7$}

\section{1 - Identificação}

Raça: - Pequinesa

Idade: -9 anos

Pelagem: - Castanha

2 - Exame clínico

Tempo de evolução: -6 meses

Sintomas: - Aumento de volume na região perineal direita. Dificuldade na defecção. Bexiga e próstata aumentada de volume presentes no conteúdo herniário.

3 - Operação praticada conforme técnica descrita.

Retirada dos pontos cutâneos 7 dias após a operação. Alta por cura.

\section{PROTOCOLO N. 8}

\section{1 - Identificação}

Raça: - Sem raça definida

Idade: -8 anos

Pelagem - Negra

2 - Exame clínico

Tempo de evolução: -3 meses

Sintomas: - Aumento de volume na região perineal esquerda. Dificuldade na defecação e micção. Bexiga e próstata aumentada de volume presentes no conteúdo herniário.

3 - Operação praticada conforme técnica descrita. por cura.

Retirada dos pontos cutâneos 7 dias após a operação. Alta

\section{PROTOCOLO N. ${ }^{\circ} 9$}

\section{1 - Iuentificação}

Raça: - Sem raça definida

Idade: -10 anos

Pelagem: - Negra

2 - Fxame clínico

Tempo de evolução: -20 dias

Sintomas: - Aumento de volume na região perineal direita. Dificuldade na defecação e impossibilidade de micção. Bexiga e próstata aumentada de volume presentes no conteúdo herniário. 3 - Operação praticada conforme técnica descrita.

Deiscência parcial dos pontos cutâneos: aplicação de antissépticos locais. 

operação.

Retirada dos pontos cutâneos remanescentes 7 dias após a

Cicatrização por segunda intenção decorridos 18 dias da oreração. Alta por cura.

\section{PROTOCOLO N. ${ }^{\circ} 10$}

\section{1 - Identificação}

Raça: - Pequinesa

Idade: $-7,5$ anos

Pelagem: - Castanha

2 - Fxame clínico

Tempo de evolução: -4 meses

Sintomas: - Aumento de volume bilateral na região perineal. Dificuldade na miç̧ão. Bexiga e próstata aumentada de volume presentes no lado direito da formação.

3 - Operação praticada conforme a técnica descrita. por cura.

Retirada dos pontos cutâneos 7 dias após a operação. Alta

\section{SUMMARY}

The present paper reports the occurrence of perineal hernia in $10 \mathrm{dogs}$, establishing the presence of the urinary bladder and the prostate as components of the hernial content. The dogs were of different breeds, their ages varying from 7 to 14 years. Five of the animals presented the process on the right side, four on the left and in only one the process was bilateral.

In the surgical reparation of the perineal hernia, as an important step to prevent reincidence of the process, the author performed the prostatectomy according to the technique recommended by Matera (1952), allowing satisfatory functional results.

The structures involved in the process were identified and utilized with the objective or complete recuperation of the anatomical region, a procedure that revealed itself as highly effective.

Until the present moment, reincidence of the process or other complications consequent to the technique employed were not verified in the cases here reported.

\section{REFERENCIAS BIBLIOGRÁFICAS}

1. ARCHIBALD, J. \& CAWLEY, A. J. - Canine prostatectomy. J. Am. vet. med. Ass., Ithaca, 128(4): 177, 1956.

2. ARCHIBALD. J. \& CAWLEY, A. J. - Complete perineal prostatectomy and repair of perineal hernia. Vet. Med., Chicago, 56(3): 73-76, 1961. 
3. BERGE, E. \& WESTHUES, M. - Técnica operatória veterinária. 2* ed. Barcelona, Editorial Labor, 1961, p. 267-270.

4. BLAKELY, C. L. - Perineal hernia. In Canine Surgery. 4th. ed. Illinois, American Veterinary Publications, Inc., 1957, $p_{4} 458-468$.

5. BRUMLEY, O. V., 1948 (apud PETTIT, G. D., 1962).

6. CADIOT, P. J. \& ALMY, J. - Traité de therapeutique chirurgicale des animaux doméstíques. V. 2. 3ème. éd. Paris, Vigot Frères, Éditeurs, 1924 , p. $389-392$.

7. CARDIOT, P. J. - Précis de chirurgie vétérinaire. 5ème. éd. Paris, Vigot Frères, Éditeurs, 1936, p. 602-604.

8. CAMPOS. V. J. M. - Contribuição ao estudo anatômico de alguns vasos arterias intrapélvicos no cẳo adulto (canis familiaris). "Tronco hipogástrico sacral" (Mannu. 1930), A Ilíaca, A. Umbilicalis, A. Urogenitalis e "A. vesical média" (Rauch, 1963). Botucatu, 1968. [Tese. Faculdade de Ciências Médicas e Biológicas].

9. CINOTTI. F. - Patologia e terapia chirurgica veterinaria. Milano, Casa Editrice Dottor Francesco Vallardi, 1948, p. 353-355; p. 392-395.

10. CINOTTI, F. - Medicina operatoria veterinaria. Milano, Casa Editrice Dottor Francesco Vallardi, 1953, p., 510-511.

11. DE VITA, J. - Factors responsible for perineal hernia in male dogs. In Canine Surgery. 4th. ed. Illinois, American Veterinary Publications, Inc., 1957, p. 456-457.

12. ELLETT, W. \& ARCHIBALD, J. - Hernia. In Canine Surgery. Fyrst Archibald edition. Illinois, American Veterinary Publications, Inc., 1965, p. $473-487$.

13. EXESTONE, H. - A successful operation for perineal hernia. Vet. Med., Chicago, 36(10): 531-532, 1941.

14. FORSSELL, G., 1937 (apud O'CONNUR, J. J., 1950).

15. GADD, J. D. - Hypertrophy of the prostate gland. J. Am. vet. med. Ass., Ithaca, 104(802): 15-18, 1944.

16. GARBUTT, R. J. - Diseases and surgery of the dog. Orange, Judd Publishing Company, Inc., 1938, p. 194; p. 255-256.

17. GORDON, N, - Surgical anatomy of the bladder, prostate gland, and urethra in the male dog. J. Am. vet. med. Ass., Ithaca, 136 (5): 215-220, 1960.

18. GUTMANN, 1908 (apud ROSSNER, J., 1958).

19. HACKL, 1920 (apud ROSSNER, J., 1958).

20. HENDERSON, $\mathbf{W}$. - Operation to correct perineal hernia, followed by ventrifixation of the bowel. Vet. Rec., London, 61(50): 830-831, 1949.

21. HERMANN, A. A. - Treatment of hyperthophy of canine prostate gland. J. Am. vet. med. Ass., Ithaca, 96(757): 547-548, 1940.

22. JAKOB, 1924 (apud ROSSNER, J., 1958). 
23. JUBB, K. V. F. \& KENNEDY, P. C. - Pathology of domestic animals. v. 1. New York, Academic Press, 1963, p. 376-378.

24. JULIAN, L, M. - The pathology of the prostate gland of man and dog: a review. Cornell Vet., Ithaca, 37(1) $\{241-253,1947$.

25. LAMY, E. - Anatomie et Chriurgie de la prostate du chien. Paris, Vigot Frères, Editeurs, 1931. [Thèse].

26. LEONARD. E. P. - Fundamentals of small animal surgery. Philadelphia, W. B. Saunders Company, 1968, p. 252-257.

27. LORD, L. H., ROWSELL, H. C., CAWLEY, A. J. \& ARCHIBALD, J. Suppurative prostatitis corrected by prostatectomy. N. Am. Vet., Evanston, 37(11): 963-967, 1956.

28. MAtera, E. A. - Prostatectomia pela via perineal no cão. São Paulo, 1952. [Tese. Faculdade de Medicina Veterinária da Universidade de Săo Paulo].

29. MATERA, E. A. \& ARCHIBALD, J. - Prostate gland. In Canine Surgery. First Archibald edition. Illinois, American Veterinary Publications, Inc., 1965, p. 591-604.

30. MC CUNN, J. - Hobday's surgical disease of the dog and cat. 6th. ed. London, Baillière Tindall and Cox, 1953, p. 272-274.

31. MENSA, A. - Patologia cirúrgica veterinaria. Barcelona, Editorial Labor, S.A., 1950, p. 1134-1137.

32. MEULleR, F. - Anatomical factors in perineal hernia. Vet. Med., Chicago, 49(2): 66, 1954.

33. MILLER, M. E., CHRISTENSEN, G. C. \& EVANS, H. E. - Anatomy of the dog. Philadelphia, W. B. Saunders Company, 1968.

34. MITCHELL, J. M. - Successful perineal hernia operation. Vet. Rec., Loudon, 60(52): $685,1948$.

35. MOLLER \& FRICK, 1921 (apud ROSSNER, J., 1958).

36. MOLTZEN-NIELSEN, H. - Perineal hernia. Int. vet. Congr., Stockholm, 2(1): 971-975, 1953.

37. MORNET, R. - Contribution a l'etude de l'hyperthophie et du cancer de la prostate du chien. Leur traitement par les oestrogènes de synthese. Paris, Imprimerie A. Chopin, 1949. [Thèse].

39. ORMROD, A. N. - Surgery of te dog and the cat. London, Baillière, lière, Tindall \& Cox, 1950 , p. 679-680.

39. ORMROD, A. N. - Surgery of te dog and the cat. London, Baillière, Tindall \& Cox, 1966, p. 159-160.

40. PETTIT, G. D. - Perineal hernia in a bitch. Can. vet. J., Ottawa, 1(11): 504-507, 1960.

41. PETTIT, G. D. - Perineal hernia in the dog. Cornell Vet., Ithaca, 12(2): 261-279, 1962.

42. PUNTONI, P. - Considerazioni su di alcunl casi di ernie perinealt nel cane. Nuova Vet., Bologna, 33(8): 327-333, $1957 a$. 
43. PUNTONI, P. - Diverticolo rettale in un cane causa di ernie perineale. Analli Fac. Med. vet. Univ. Pisa, 10: 159-167, 1957b.

44. ROSSNER, J. - Uber hypertrophie, cysten und abszesse der prostata des hundes. Tierärztl. Umsch., Kontanz, 13(12): 381-388, 1958.

45. SCHLOTTHAUER, C. F. - Observations on the prostate gland of the dog. J. Am. vet. med. Ass., Ithaca, 81(5): 645-650, 1932.

46. SCHLOTTHAUER, C. F - Disease of the prostate gland in the dog. J. Am. vet. med. Ass., Ithaca, 90(2): 176-187, 1937.

47. SISSON, S. - Anatomia de los animales domésticos. Barcelona, Salvat Editores, 1933.

48. SPARKS, E. R. - Prustatectomy in the redution of perineal hernias in the dog. Vet. Med., Chicago, 28(12): 508-511, 1933.

49. THAYER, C. B. - Surgical correction of a perineal hernia. Vet. Med. Chicago, 43(1): 35-36, 1948. 